\title{
Drivers of Firm's Value: Panel Data Evidence from Indian Manufacturing Industry
}

\author{
RanjitTiwari \\ Fellow, NIFM \\ IILM Graduate School of Management \\ Greater Noida, India - 201306 \\ Brajesh Kumar \\ National Institute of Financial Management \\ Faridabad, India - 121001
}

Received: March15, 2015 Accepted: June14, $2015 \quad$ Published: December 1, 2015

doi:10.5296/ajfa.v7i2.7243 URL: http://dx.doi.org/10.5296/ajfa.v7i2.7243

\begin{abstract}
The purpose of this paper is to classify the value drivers into broad categories and then identify the major drivers of firm's value for Indian manufacturing industry and also work out the sectorial sensitivity of value drivers. To achieve the objectives of the study we first derive the value driver's model next we use panel regression with different model specifications to empirically analyse the major drivers of firm's value.Ourstudy reveals that sales, net margin, book value, dividend per share, beta and earnings per share are the six major financial drivers of value. All the strategic drivers when included in the model have significant relation with value without disturbing the r-square of the model. Thus, it is clear that apart from generic financial drivers, firms need to put more attention on strategic choices they make, because it is the strategic choice that will give firms an edge over others in developing economies like India. Further, we also observesector specific priorities of the value drivers. This paper provides academicians and practitioners with an overview of the applicability of value drivers for Indian manufacturing industry. Further, the study will fill the gap in literature by adding value drivers' evidence from one of the fastest growing economies in the world and will benefit researchers in arriving at common consensus for value drivers in emerging economies.
\end{abstract}

Keywords:Drivers, Firm value, Manufacturing, Panel data analysis, India. 


\section{Introduction}

Investment funds are limited and to attract them, the firm has to submit itself to the scrutiny of the people whose money it is using.In this scenario, the firm's that can create value ${ }^{1}$ for their shareholder and stakeholders ${ }^{2}$ are now most preferred. If the management of the firm can identify the unique drivers that have higher influence on market valuethen it will eventually increase shareholder value by managing those drivers. This is in line with argument that the managers first priority is to maximise ${ }^{3}$ the shareholder value (see, Rappaport (1986), Black et al. (2001), Chandra (2011) among others). In the next section, we further dwell on this issue in more detail.

Given the importance of the issue, many researchers have tried to identify the value drivers. However there is no unanimous approach towards these drivers as well as their classification. Moreover, the empirical literature on developing economies is very scant ${ }^{4}$. This has fuelled our interest to study the drivers of firm's value in an emerging economy context which are growing at high speed (see, footnote 5) and are able to attract foreign investment because of huge untapped market and low cost labour.

In line with the above discussion, the objectives of this study is to first classify the drivers into broad categories and then identify the major drivers of firm value for Indian manufacturing industry and also work out the sectorial sensitivity of value drivers. More specifically, we try to develop an understanding as to which are the key drivers the companies should concentrate on that will improve performance and hence create value. To our knowledge, this is among the few studies that provide large scale evidence on value drivers of firms' in developing economies. This paper will provideacademicians and practitioners with an overviewof the applicability of value drivers for Indian manufacturing industry that may lead to increased profitability. Further, the study will fill the gap in literature by adding value drivers' evidence from one of the fastest ${ }^{5}$ growing economies in the world.

While doing driver analysis we will concentrate on historic facts and empirically examine the relationship between value and potential drivers (see, section 3 for details). Rest of the study isorganised as follows: section 2 provides brief review of literature, section 3 provides derivation of value drivers' model, section 4 and 5 briefs data and methodology used for the study, section 6 provides empirical results and finally section 7 provides concluding remarks.

\footnotetext{
${ }^{1}$ We define value as change in stock prices of firms over a period.

${ }^{2}$ Corporate success in creating shareholder value benefits all parties, not only shareholders. Economic surpluses make everyone better off. It is difficult to imagine a business where you can satisfy shareholders without taking care of customers, employees and others. In the pursuit of economic value creation, management must concern itself with all aspects of company operations, including product quality, personnel training, know-how, company image, and reputation. Hence, the pursuit of economic value is consistent with the interest of all parties. Failure to which may lead to reduction in shareholder value in long run (see, Rappaport, 1998; Black et al., 2001; and Morin et al., 2004).

${ }^{3}$ Much of the theory of corporate finance is based on the assumptions that since managers are hired by shareholders they should strive to maximise the value of firm or shareholder value.

${ }^{4}$ The review of studies in section 2 reveals that majority of the studies are conducted with respect to developed nations and we are using those drivers as a proxy for measuring and/or managing performance of companies in developing nations, even after knowing the fact that the level of market efficiency and structure is different. Hence we need studies that can bring forward the story of emerging nations. This study is a way forward in this direction that takes up the case of India.

${ }^{5}$ See, Trade and development report 2013 and World investment report 2014.
} 


\section{Review of literature}

For the purpose of firm's valuation, it is very essential to identify the key drivers of value because these drivers can either increase or decreasethe value depending upon the tendencies of their changes (see, Kazlauskiene and Christauskas (2008)).Several studies (both quantitative and qualitative) have investigated the drivers influencing firm value to have a better understanding of these drivers. Chugh and Meador (1984) did a survey of 2000 members of financial analysts' federation and indicate that analysts consistently emphasise the long term over the short term. The study revealed that expected changes in EPS, expected return on equity, and prospects for the relevant industry were considered to be the most essentialvariables over the long term whereas industry prospects, expected changes in EPS and general economic conditions were given high importance in the short term. Ruhland Cowen (1990) focused on the methods of creating shareholder value using an internal financial planning and control system. They stated that since return on investment, return on equity, and earnings per share figures can be manipulated by management, thereforethese variables fail to sufficiently measure a firm's performance. They alternatively suggestedfive drivers that are likely to affect cash flows namely: operating profit margins, working capital investment, sales growth rates, fixed capital investments, and cost of capital. Following similar lines Mills and Print (1995), Scarlet (1997), Rappaport (1998) and Black, Wright and Davies (2001) in their books point out seven value drivers namely: change in sale, margin of activity profit, tax rate, working capital, expenses of capital, costs of capital, and period of competitive advantage. In addition to the above mentioned drivers, Turner (1998) presented the eighth driver i.e. return on capital.

Kaplan and Norton (1996) have divided value drivers into four categories: financial, purchasers, internal business process, and innovations which leads to the determination of seven value drives namely return on capital employed, account receivables, operating expenses, customer satisfaction, lower rework, employee morale and employee suggestion. L.E.K. Consulting (1998) executive insights have classified value drivers into three broad categories: growth drivers, efficiency drivers and financial drivers. Further, they suggested that by focusing on these value drivers, management can prioritise the specific activities that will affect performance in each area.Cheremnikh(2000) as cited in Kazlauskiene and Christauskas (2008) in his study on improving company's value for the purpose of business management classified value drivers into three broad groups with two levels each namely internal and external value drivers, quantitative and qualitative value drivers, and financial and non-financial value drivers.Ittner and Larcker (2001) using value based management perspective tried to identify the factors influencing the performance of firms. They, based on perceived importance presented the following categories of value drivers: financial, purchasers, employees, operational, quality, alliances, supply, environment, innovations, and society. They further examined the relative importance of these value drivers under four different strategic dimensions of firms namely: flexibility, innovation, market stability, and book to market ratio and suggested that different strategies attract different drivers.

Akalu (2002) suggested that it is extremely important to know the strength of value drivers to understand their influence in the process of free cash flow generation. He have considered net 
sales, operating cost, interest expenses, income taxes, fixed cost of investments, replacement cost of investment and working capital investment as initial value drivers in the model. However income tax, investment cost and working capital are the three major drivers of value. Xavier and Vinolas(2003) suggested a fresh corporate valuation method "Financial and Economic value added," or FEVA that integrates the EVA, DCF, and MM approaches. The FEVA approach divides the sources of corporate value into eight value drivers (capital invested, current operating EVA, Franchise factor from new investments, tax shield on existing debt, tax shield from growth opportunities, bankruptcy cost of current debt, bankruptcy cost of new debt, current debt) and precisely identifies the contribution of each driver. Kim (2004) proposed a model to empirically identify the critical strategic factors for value-based management. Since "value" is abstract in its nature, managers of the firms need to know more solid and clear target measures that derive the value of their firm. The proposed model uses common financial factors and their variations as input variables to produce the market value added (MVA). Further to capture a dynamic relationship between input and output variables the model uses an artificial intelligence technique that is non-parametric by nature. Findings of the study reveal that the model is able to identify a set of strategic drivers that are linked directly to the MVA of companies involved. Specifically, cost of capital and size of capital are the two most important factors creating value.

Morin and Jarrell (2004) have prescribed a value based management framework putting it all together the strategic, financial and corporate governance issues to determine the value drivers for companies. Finally consolidating all the three issues they have classified value drivers in two levels. Level one constitutes of cash flows and cost of capital and level two constitutes of return, growth rate and capital that determines cash flow and risk that determines cost of capital.Kakati (2005) has tried to identify the factors that have an influence on stock valuation process. He found that though stocks response to some common factors, they appear to response to specific factors like price earnings ratio, return on net worth, earnings per share, growth in sales, dividend per share and analysts forecast i.e. to say that financial factors influence the stock valuation process but other non-financial, industrial and economic factors have little influence. Moreover he argued that the use of large number of factors in the model does not lead to better performance of stocks. Hence, what is important is the reliable sources of information, better forecasting and accuracy of valuation techniques.Gross (2006) in his study have identified the business mix, the branch structure, the cost efficiency and the risk capabilities as potential value drivers. Further they examined their impact on value creation. They suggested that the cost efficiency and the risk capabilities are the two essential drivers of shareholder value whereas the empirical evidence on the business mix and the branch structure is ambiguous. Kraai (2006) suggested that business environment at present is not just about survival; it's about focusing on and creating sustainable value. Kraai in his review suggested that over 26 value drivers have been identified but typically no more than 10 are critical in any business. The ten most common value drivers are: management depth, customer diversity, owner involvement, competition, customer satisfaction, human capital, financial history, operating efficiencies, recurring revenue and professional sense. 
Damodaran (2006) in his study have given stress on individual characteristics of firm's i.e. cash flows, expected growth rate and discount rate to be the most important drivers of value in any firm. He also suggested that since equity valuation through multiples approach is the most common approach among analysts hence, the fundamental drivers of equity multiples approach will be of great use in creating and/or managing value of the firm's. The fundamental drivers of three widely used multiples (P/E, P/B and P/S multiple) among analysts where expected growth rate, pay-out ratio, risk, return on equity and net margin.Kazlauskiene and Christauskas (2008) suggested that the classification of value driver is subject to the disintegration of firm's value established by the method of discounted cash flows, because all the drivers that have an impact on firm's value are reflected in the rates of free cash flows and discount rate. They have classified the drivers into five levels and suggested to establish the impact of drivers on firm's value through an integral method of economic factor analysis. Boyd (2010) based on his past experience of advising professionals in the field of valuation have identified six key value drivers that are common to most businesses that includes: management team, operating system, customer base, facilities and equipment's, growth strategy and financial controls. He suggested that concentrating on developing and enhancing each of these value drivers will create value for the firm. Chandra (2011) has conceptualised the important levers that are available to a company for managing and creating value in a 'value octagon' that includes strategy and business model, capital allocation, strategic financial decisions, organisational architecture, cost management, corporate risk management, mergers/acquisitions/restructuring, and corporate governance.

In a recent study Chang and Hughes(2012) concentrated on the innovative skills of small and medium enterprisesas a driving factor that will have a positive impact on firm's performance. They suggested that firm's performance is linked to innovation, which in a way is linked to other driving forces such as organisationalstructure and leadership style. Al-Hares, Abu-Ghazaleh and Haddad (2012) empirically investigated the value relevance of earnings, book value and dividends in an emerging capital market and reported that book value and earnings are two major factors that are playing an important role in improving value. Their results are consistent with Ohlson (1995).

Taking into account the value influencing drivers mentioned by the authors analysing firm valuation issues, it is noticed that no consensus so far has been reached regarding the major driving forces behind firm value. We also miss a uniform approach towards these drivers as well as their classification. Moreover, the empirical literature on developing economies is very scant. Hence, it is of great interest to determine the value driver's model for Indian firms. Doing so will enable the management to translate the broad objective of creating value into some specific actions more likely to deliver that value.

\section{Derivation of value driver's model}

Value drivers are the factors that may influence the value creation of a firm (e.g. profitability, management quality, customer satisfaction, macro-economic factors etc). The value drivers have been broadly classified into two dimensions(See, Griaznova and Fedotova (1998), Cheremnikh (2000), Ripol-Saragosi (2001) and Gross (2006)). The first dimension is based 
on the internal and external aspects. Internal value drivers are factors relating to the inherent performance of a firm, whereas external drivers are factors relating to the macro-economic environment. The second dimension takes the qualitative and quantitative aspects of value drivers. Quantitative value drivers are factors concerned with the collection and analysis of data in numeric form, whereas qualitativevalue drivers, on the other hand, refers to descriptions based on some quality or characteristic of the firm. Qualitative value drivers do have a significant impact on firm's value but unfortunately, information on these qualitative drivers is typically not available and if available, its impact on value is difficult to measure because of its non-quantifiable nature (see, Gross (2006)).

For clarity of presentation, the two dimensions can be represented in atabular form as follows:

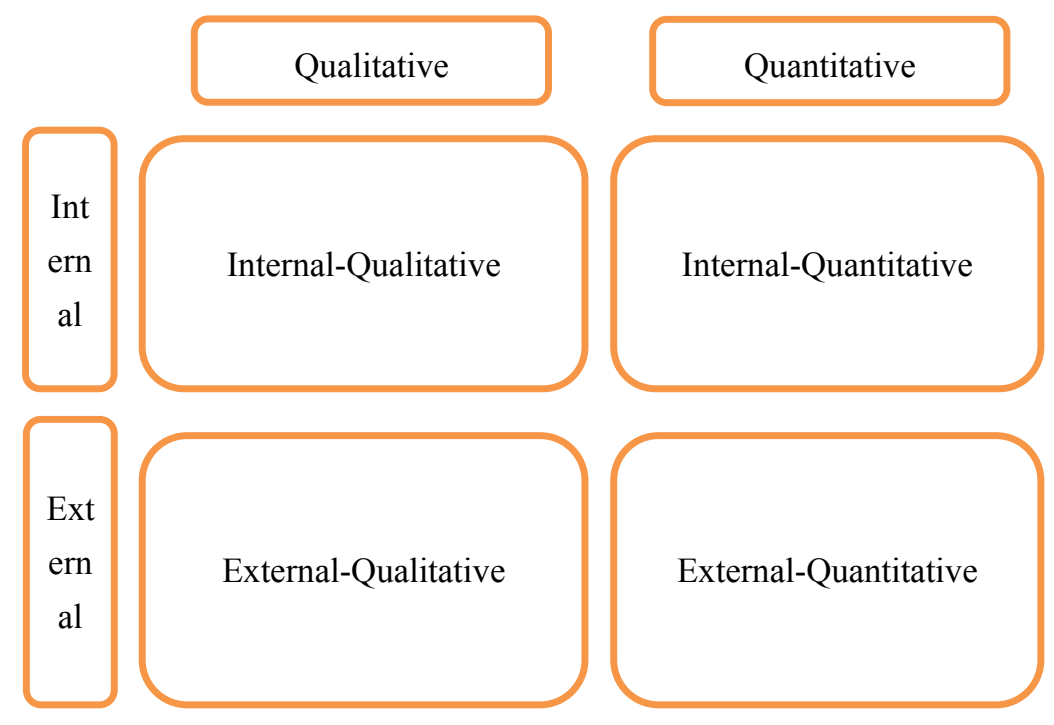

Figure 1.Types of value drivers

Source: Own modified graphic

The top-left quadrant of the Fig 1, represents the internal qualitative (e.g. firm specific attributes like management quality, corporate governance) aspects. Similarly, the top-right quadrant gives the internal quantitative (e.g. financial indicators) attributes. Likewise, the bottom-left and the bottom-right represent the external qualitative (e.g. credit rating, consumer behaviour) and external quantitative (e.g. macro-economic factors) aspects, respectively.

Since, we choose model decomposition ${ }^{6}$ process to arrive at the value drivers, our modelRIMthat we choose based on superiority of residual income model over other valuation models ${ }^{7}$ is more suited for internal-quantitative attributes;hence, we only incorporate

\footnotetext{
${ }^{6}$ Because models are used to estimate the intrinsic values therefore it is of utmost interest to dig out the drivers responsible for increase or decrease in value estimated with the help of these models.

${ }^{7}$ Because under residual income model value is recognized early since a major portion of the stock's intrinsic value is constructed immediately in the form of current book value and terminal values are less sensitive. Moreover residual income models are based on economic profitability of a firm rather than just its accounting profitability. Major studies on valuation
} 
internal-quantitative factors in our analysis. Moreover, RIM model is better fitted in our study as it is more informative than other value estimate models. We take this approach further and considered it for the derivation of value drivers.

We construct a value metrics framework (see, figure 2), to derive the potential drivers of firm value. First, we approximate the value of a firm with our estimated intrinsic value.Next, we link this value estimate to the financial indicators of the firm directly linked to the model that is used to arrive at the intrinsic value.For the estimation of the intrinsic value, we have used different financial indicators ${ }^{8}$ of the firmdirectly linked to the model and name the indicators as 'Level I Financial Indicator'(see, figure 2). These 'Level I Financial Indicator'are again a function of multiple factors ${ }^{9}$ (see, figure 3). We define the multiple factors as 'Level II Financial Indicator'(see, figure 2). Both the 'Level I Financial Indicator'and 'Level II Financial Indicator' are our financial value drivers.

But as we know, market value of a firm is also dependent on other factors that have an impact on firm's value. These factors may not be directly associated to the model; e.g. the strategic choices of companies for their growth and development,managing investor perception etc. We call them indirect financial indicators or 'strategic value drivers'. The four probable strategic drivers of value are assumed to be pay-out ratio, investments into $R \& D$, investments into advertisement (brand image), and participation of foreign promoters in the organisational structure of the firm (see, Walter (1963), Chaganti and Damanpour (1991), Salomo and Strecker (2009) among others). We therefore classify value drivers into two broad categories namely financial value drivers and strategic value drivers (see, figure 4). Further, we anticipate that market values of firms are correlated to the probable drivers of value. Therefore to measure the impact of the identified value drivers, we formulate the regression model as illustrated in equation 1.A brief description of the identified value drivers are presented in table 1.

Table 1.Brief description of the identified value drivers

\begin{tabular}{|c|c|c|}
\hline Drivers & Description & Proxy variable used \\
\hline Sales revenue & $\begin{array}{l}\text { Income from sales of goods and services, minus the cost associated } \\
\text { with things like returned or undeliverable merchandise in the normal } \\
\text { operations of a company in a specified period. We expect that high } \\
\text { revenue growth will lead to higher value. }\end{array}$ & Sales (S) \\
\hline
\end{tabular}

of models also reveal the superiority of RIM over other models (see, Bernard (1995), Penman and Sougiannis (1998), Frankel and Lee (1995; 1996), Francis, Olsson, and Oswald (2000), Gross (2006), Subrahmanyan and Venkatachalam (2007), Imam, Chan and Ali-Shah (2013)).

${ }^{8} \mathrm{We}$ have considered return on equity, growth, Cost of equity, and book value amongthe financial indicators.

${ }^{9}$ Level II financial indicators are arrived at by decomposing level I financial indicators. For example, return on equity can be derived from change in sales, change in operating expense, change in tax rate and change in net margin. Similarly, change in sales and change in capital expenditure can be used as proxy for growth of the firm. Cost of equity can be analysed by three drivers: market return, risk free return and beta. Book value is arrivedat by lagged book value, earnings per share and dividend per share (see, Rappaport (1998); Lee et al. (1999) and Black and Wright (2001)).However, Level II financial indicators reported in figure 2 only reports the unique drivers of decomposed level I financial indicators. 


\begin{tabular}{|c|c|c|}
\hline Operating cost & $\begin{array}{l}\text { Operating costs include both fixed costs and variable costs. So any } \\
\text { increase in cost will be a reduction in value. But cost may also rise to } \\
\text { achieve higher production activities. So we measure the operational } \\
\text { efficiency by intensity of operating cost. We expect that high intensity } \\
\text { of cost will lead to lower value. }\end{array}$ & OC / Sales (IOC) \\
\hline Tax rate & $\begin{array}{l}\text { Total tax liability stated as a percentage of the taxable income. High tax } \\
\text { rate will therefore reduce earnings available for equity shareholders } \\
\text { that will lead to lower value. }\end{array}$ & Total tax / PBT (TR) \\
\hline Net margin & $\begin{array}{l}\text { Net margin is a measure of firm's profitability, hence will lead to higher } \\
\text { market value for the stocks. }\end{array}$ & Net profit / Net Sales (NM) \\
\hline Capital expenditure & $\begin{array}{l}\text { Funds used by a company to acquire or upgrade physical assets creating } \\
\text { future benefits. Capital expenditure will though reduce free cash flows } \\
\text { of the business but will work as an agent of cash flow generation in } \\
\text { future. Hence, lagged value of Net change in fixed assets is used. }\end{array}$ & $\begin{array}{l}\text { Net change in fixed assets } \\
\text { (CAPEX) }\end{array}$ \\
\hline Book value & $\begin{array}{l}\text { The value at which an asset is carried on a balance sheet. It is the total } \\
\text { value of the company's assets that shareholders would theoretically } \\
\text { receive if a company were liquidated. Therefore higher (lower) } \\
\text { estimates of book value may lead to higher (lower) market value. }\end{array}$ & BV \\
\hline Earnings per share & $\begin{array}{l}\text { The portion of a company's profit allocated to each outstanding share } \\
\text { of common stock. Earnings per share serve as an indicator of a } \\
\text { company's profitability. }\end{array}$ & EPS \\
\hline Dividend per share & $\begin{array}{l}\text { The portion of companies' profit that is distributed among } \\
\text { shareholders. Market reacts positively to announcements of dividend } \\
\text { increases, and negatively to announcements of dividend decreases or } \\
\text { no dividend. }\end{array}$ & DPS \\
\hline Beta & $\begin{array}{l}\text { It is a measure of systematic risk, of a security in comparison to the } \\
\text { market as a whole. Therefore it is expected that stocks with higher beta } \\
\text { will form the basis of higher discount rate and hence lower value. }\end{array}$ & Beta \\
\hline Pay-out ratio & $\begin{array}{l}\text { Pay-out ratio plays an important role in emerging economies because } \\
\text { company's decision on whether it will pay high percentage of profits as } \\
\text { dividends or will retain them for future expansion is a critical decision } \\
\text { to be made because high pay-out ratio is perceived as low level of } \\
\text { investments opportunities available to firms and vice-versa in the } \\
\text { market and hence will lead to lower/higher market value. }\end{array}$ & POR \\
\hline Ownership structure & $\begin{array}{l}\text { By ownership structure we mean the participation of foreign promoters. } \\
\text { We expect that high concentration of foreign promoters will have } \\
\text { significant positive influence on firm value. The underlying rational is } \\
\text { that apart from easy money, foreign promoters will bring new } \\
\text { technologies and human expertise with them, which will in a way help } \\
\text { firms in developing economies to grow and survive in the competitive } \\
\text { world. }\end{array}$ & Foreign promoters (FP) \\
\hline
\end{tabular}


Investments into R\&D

Investments into $R \& D$ is viewed as the future of firms performance because to survive in this competitive market it is expected that firms come up with new innovative products and services, and that is only possible if firms are continuously investing into $R \& D$. We expect the

market value of firms with high investments into $R \& D$ be higher than firms with low or no investments.

Investments into advertisement are a measure of brand image. The firms with high brand value are perceived to have better future Investments into prospects because of the trust created by them over years. We expect

advertisement the market value of firms with high investments into advertisement be higher than firms with low investments.

\section{Source: Own compiled}

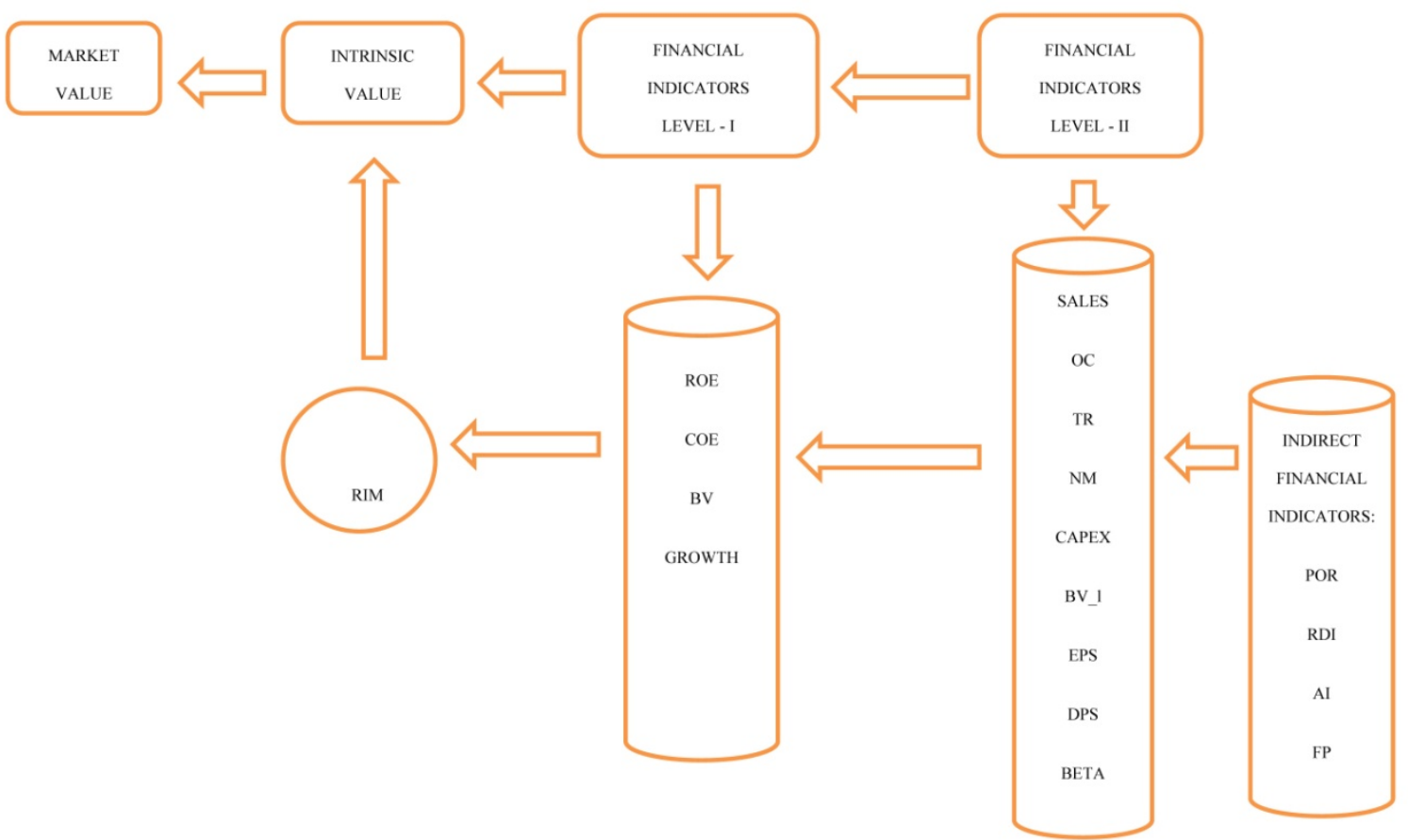

Figure 2.Model derivation process

Source: Own graphic 


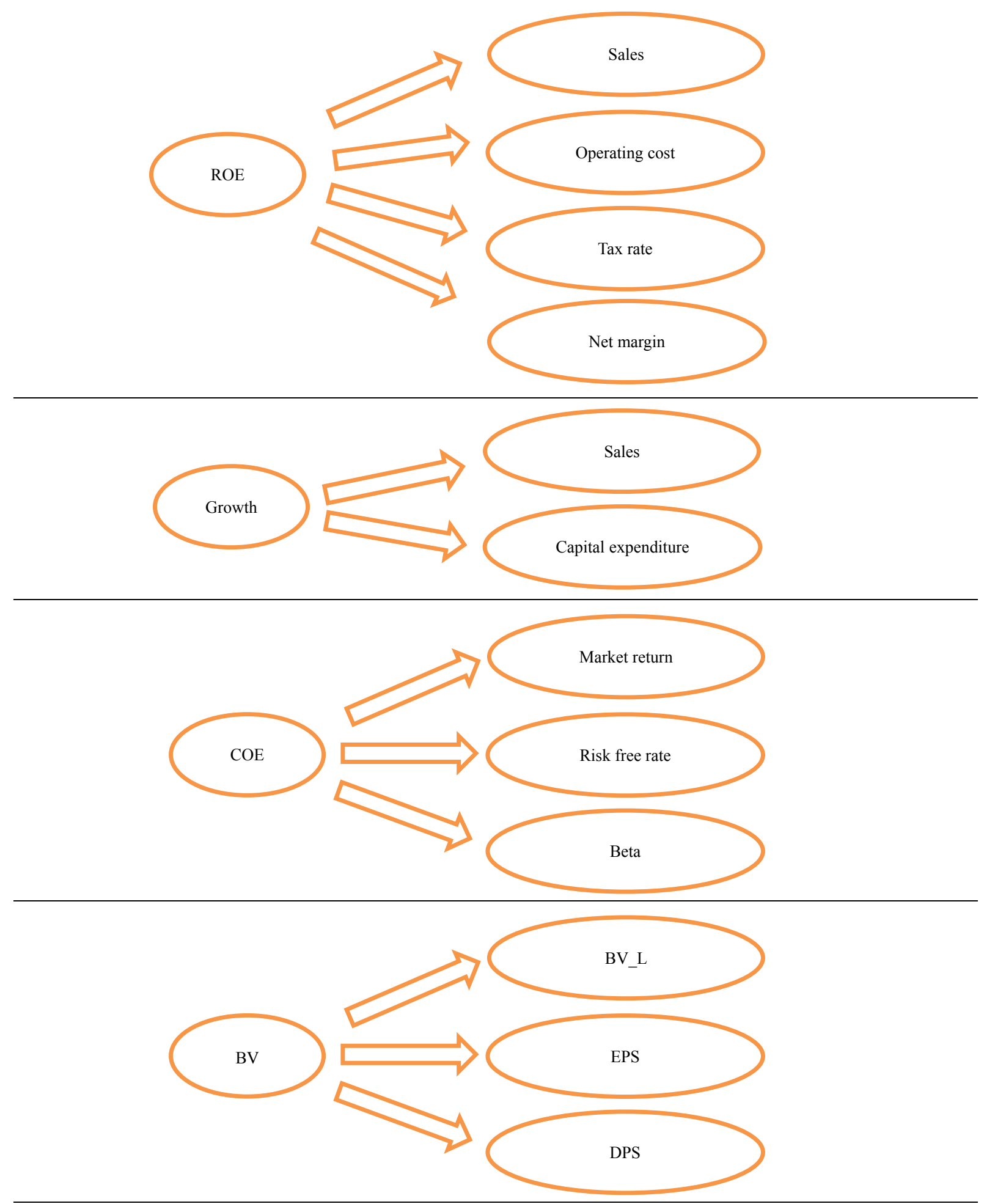

Figure 3. Derivation of level II value drivers

Source: Own graphic 


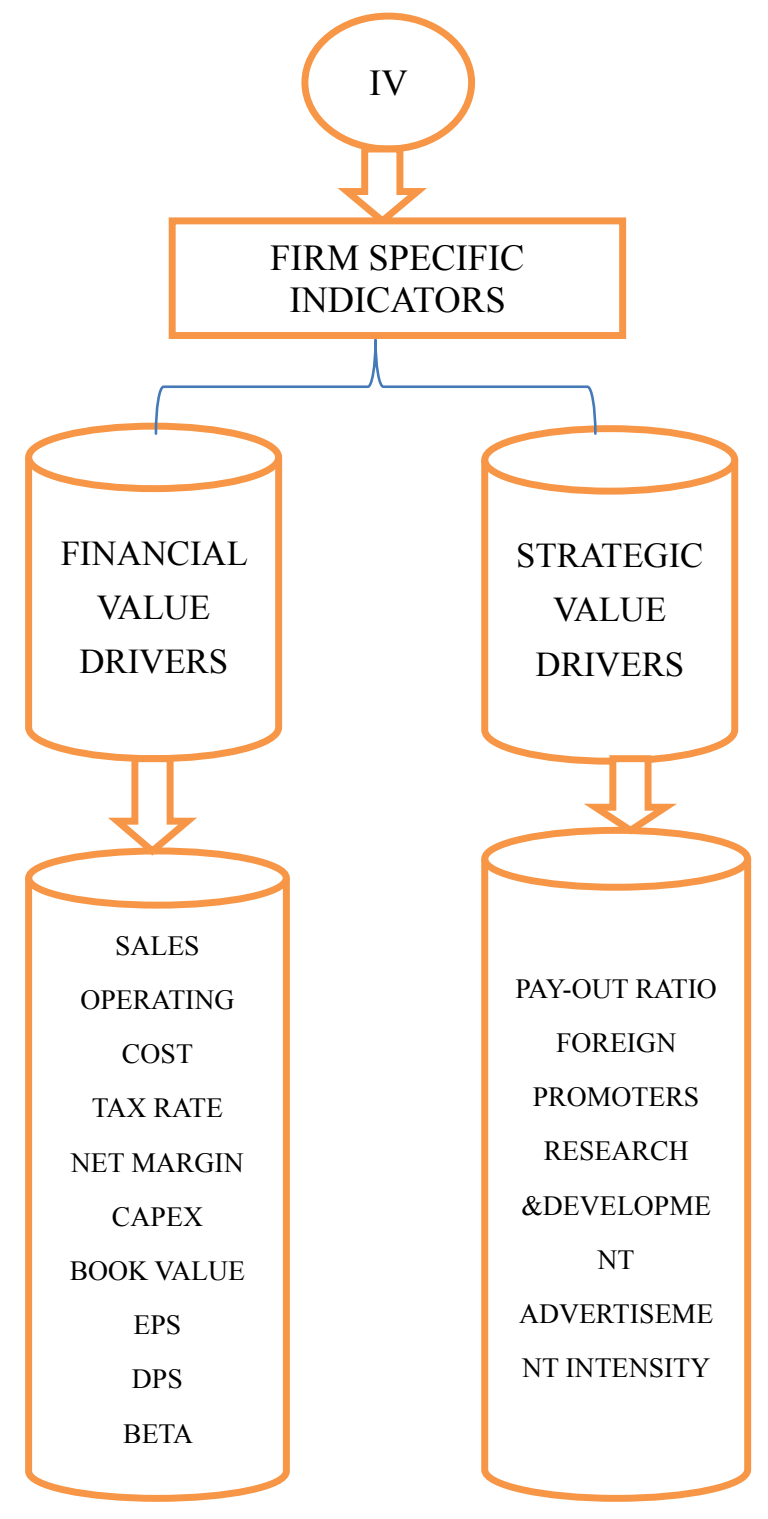

Figure 4. Classification of value drivers

Source: Own graphic

\section{Data sources}

All the variables used in this study were obtainedfrom the prowess data base of Centre for Monitoring Indian Economy (CMIE). It provides data on more than 27000 Indian companies both listed and unlisted. We have taken all 3756BSE (Bombay Stock Exchange) listed manufacturing companies from prowess data base for the period from March 2002 to March 2012. The study further analyses the sectorial sensitivity of value drivers for the seven sub-sectors of manufacturing industry (as per CMIE)namely Chemical, Machinery, Metal, Non-metallic, Transport, Textile and Food \& Beverages sector.

\subsection{Sample selection}

We start withall the 3756 BSE listed manufacturing sector companies for 11 years.Out of these 3756 companies, we further filter it on the basis of availability of positive book value, 
adjusted closing price andfirms with minimum two years of data. This resulted in our final sample size reduced to 1372 firms. The breakup of these firms into different segment has been depicted in the table 2.To obviate the effect of extreme outliers on our results, we winsorize the data by 2.5 percent top and bottom. Descriptive statistics of the variables are reported in table 4.

Table 2. Final selection of companies

\begin{tabular}{c|c|c}
\hline Sub-sectors & $\begin{array}{c}\text { Considered firms for the } \\
\text { study }\end{array}$ & Selected firms for the study \\
\hline Chemical & 1073 & 417 \\
Machinery & 558 & 228 \\
Metal & 500 & 161 \\
Non-metallic & 292 & 100 \\
Transport & 173 & 102 \\
Textile & 585 & 202 \\
Food \& Beverages & 575 & 162 \\
\hline Total Manufacturing & 3756 & 1372 \\
\hline
\end{tabular}

Source: Own computed

\section{Methodology}

This part of our analysis aims to assess the impact of drivers on firm's value. For this purpose, we construct the value driver's model (see, equation 1) and estimate it with pooled OLS regression,the fixed effects model (FE)andthe random effects model (RE). The best model specification is identified amongst these three models to study our objective. We use F-test, LM-test and Hausman test to identify the best model specification. Further, we also conduct F-test to see the joint insignificance of coefficients i.e. to suggest that the models are well specified.

$$
\begin{gathered}
Y_{i, t}=\beta_{0}+\beta_{1} x_{1 i, t}+\beta_{2} x_{2 i, t}+\beta_{3} x_{3 i, t}+\beta_{4} x_{4 i, t}+\beta_{5} x_{5 i, t}+\beta_{6} x_{6 i, t}+\beta_{7} x_{7 i, t}+\beta_{8} x_{8 i, t} \\
+\beta_{9} x_{9 i, t}+\beta_{10} x_{10 i, t}+\beta_{11} x_{11 i, t}+\beta_{12} x_{12 i, t}+\beta_{13} x_{13 i, t}+\mu_{i, t}
\end{gathered}
$$

where: $\mathrm{Y}$ is market value ${ }^{10}(\mathrm{MV}) ; x_{1}$ islogarithm of sales $(\mathrm{S}) ; x_{2}$ isintensity of operating cost (IOC); $x_{3}$ istax rate (TR); $x_{4}$ is net margin (NM); $x_{5}$ islogarithm CAPEX; $x_{6}$ isBV_L; $x_{7}$ isEPS; $x_{8}$ isDPS; $x_{9}$ isBeta; $x_{10}$ is pay-out ratio (POR); $x_{11}$ isadvertisement intensity $^{11}$ (AI_d); $x_{12}$ isR\&D intensity $^{12}$ (RDI_d); $x_{13}$ is ownership structure ${ }^{13}$ (FP_d), $\beta_{0}$ is constant,

\footnotetext{
${ }^{10}$ Market price per share is the proxy for market value.

${ }^{11}$ AI_d is a dummy variable which takes the value of 1 if the firms are investing more than 10 percent of sales towards advertisement, otherwise its 0 .

${ }^{12}$ RDI_dis a dummy variable which takes the value of 1 if the firms are investing more than 2 percent of sales towards research \& development, otherwise its 0 .

${ }^{13} \mathrm{FP} \_\mathrm{d}$ is a dummy variable which takes the value of 1 if the firms have more than 10 percent foreign promoters in their
} 
$\beta_{1}$ to $\beta_{13}$ are coefficients.

\section{Empirical results}

In this section, we discuss the influence of value drivers on firm's value to have a critical understanding of the major drivers of value. To do this, we first need to identify the best model specification. The pooled regression model assumes homogeneity of the parameters, abstracting from heteroscedasticity and autocorrelation. The omission of firm and time-variant variables in the pooled regression model might lead to a bias in the resulting estimates. So, we relax the restrictive assumption of parameter homogeneity and run fixed effects model to gain further insights into the hypothesized relationship. Further, to reap the benefits of increased accuracy in absence of effect endogeneity, we also run random effects model. To identify the best fit among panel OLS, FE and RE we apply the standard diagnostic tests i.e. we perform F-test to choose between panel OLS and FE, Breusch and Pagan LM test to choose between panel OLS and RE, and Hausman test to choose between FE and RE (see, Reyna(2010)). The diagnostic reveals that both FE and RE are better than OLS. Now we need to determine the appropriate panel data model i.e. fixed effects or random effects model using Hausman Test. The test suggests that fixed-effects model is better than random effects (see, table 5 for discussion).

Test results of fixed-effects model represented in table 3, suggests that the coefficients for $\mathrm{S}$, NM, BV_L, EPS, DPS, Beta, POR, AI_d and FP_d were statistically significant at 1 percent level whereas IOC and RDI_d are statistically significant at 10 percent level. But the model does not yield any significant relation with TR and CAPEX.The high $R^{2}$ of 0.82 implies that the independent variables explain a large portion of the variation of the dependent variable. The F-statistic is 33.52, which rejects the null hypothesis of joint insignificance of coefficients and therefore suggests that the regression model is well-specified.

Finally based on above results we conclude that sales, net margin, book value, dividend per share, beta and earnings per shareare the six major financial driversof valuein Indian manufacturing industry. The sign and the magnitude of the estimates are on the expected lines.Net Sales is positively linked with the value of firm indicating that growth in the revenue of firm, increases profitability hence pushes the value northwards. The significant coefficients of net margin, book value, earnings per share, and dividend per share are positively linked to value. These variables are indicators of better performance of the company that translates into increased value of the firm. The highly significant and positive coefficient of beta suggest that investor's factor-in for the high risk associated with the manufacturing segment in-lieu of higher return, which increases the market value of the firms in rising markets because of huge cash flows. Though beta increases the discount rate but the increase in cash flows is disproportionate to the change in discount rate and that forms the basis of higher market value. The results also highlight that during the study period there has been no substantial investment in plant and machinery by the manufacturing segment. This can be corroborated with the fact that no significant relation is established between capital expenditure and market value. The model is also not able to establish any significant

organisational structure, otherwise its 0 . 
relationship between intensity of operating expense and market value at 5\% level. But its significance at $10 \%$ level leaves the caution behind that any mismanagement in operating expenses could lead to decline in value.

As far as strategic drivers are concerned, we find that pay-out ratio is inversely related to value at 5 percent level of significance. Hence, we conclude that firms in emerging economies like India should concentrate more on profitable investment opportunities meaning retention should be given more priority. The other three strategic driver's i.e. AI, FP and RDI have significant positive relation with value. Therefore, the firms that are concentrating on these strategic drivers can command a premium for their stock over those who have ignored these strategic choices in their business model (see, table 3).The striking aspect that can be noticed from the results is the significant relation of all the strategic drivers with value without impacting the r-square of the model. Hence, any increase/decrease in the parameters of strategic drivers, will lead to the increase/decrease in value of the firm. From this we can safely conclude that strategic driversassume higher importance than the financial drivers.

Table 3.Panel multivariate regression of value drivers (manufacturing)

\begin{tabular}{|c|c|c|c|c|c|c|}
\hline \multicolumn{7}{|c|}{ Sample size, $2002-2012, N=1372$} \\
\hline \multirow{2}{*}{ Statistic } & \multicolumn{2}{|c|}{ Panel OLS } & \multicolumn{2}{|c|}{ Fixed effects } & \multicolumn{2}{|c|}{ Random effects } \\
\hline & Coefficient & t-Statistic & Coefficient & t-Statistic & Coefficient & t-Statistic \\
\hline$\beta_{0}$ & $15.9518 * * *$ & 1.8073 & $34.3041^{*}$ & 3.9337 & $26.4282 *$ & 3.2004 \\
\hline $\mathrm{S}$ & $0.0226^{*}$ & 13.3013 & $0.0488^{*}$ & 21.7871 & $0.0411^{*}$ & 21.2439 \\
\hline IOC & $-0.1746^{* * *}$ & -1.9422 & $-0.1431 * * *$ & -1.6909 & $-0.1748^{* *}$ & -2.1816 \\
\hline TR & $0.6855^{*}$ & 3.5364 & -0.1337 & -0.5297 & 0.3508 & 1.6393 \\
\hline NM & $0.2318^{* *}$ & 2.1081 & $0.4933^{*}$ & 5.4108 & $0.4913^{*}$ & 5.5602 \\
\hline CAPEX & $-0.0032 *$ & -7.5978 & 0.0002 & 0.3907 & $-0.0016^{*}$ & -3.3452 \\
\hline BV_L & $0.5691^{*}$ & 31.4471 & $0.1810^{*}$ & 9.0008 & $0.3335^{*}$ & 18.4765 \\
\hline EPS & $2.4374 *$ & 21.8194 & $1.8913^{*}$ & 20.5153 & $2.0425^{*}$ & 22.8353 \\
\hline DPS & $7.3140^{*}$ & 21.4683 & $2.3939^{*}$ & 7.7672 & $3.3593 *$ & 11.3898 \\
\hline BETA & -2.0580 & -0.8811 & $9.7303^{*}$ & 4.3203 & $7.2048^{*}$ & 3.4027 \\
\hline POR & $-0.2596^{*}$ & -4.9431 & $-0.1595^{*}$ & -3.4221 & $-0.1399^{*}$ & -3.1296 \\
\hline AI_d & $47.7922 *$ & 11.1402 & $17.6007^{*}$ & 3.4975 & $29.1270^{*}$ & 6.3979 \\
\hline RDI_d & $52.9834 *$ & 9.4085 & $10.3664 * * *$ & 1.6694 & $24.0900 *$ & 4.2141 \\
\hline FP_d & $51.2832 *$ & 18.5931 & $13.4908^{*}$ & 2.7404 & $39.5871^{*}$ & 10.4299 \\
\hline R square & \multicolumn{2}{|c|}{0.5553} & \multicolumn{2}{|c|}{0.8204} & \multicolumn{2}{|c|}{0.3101} \\
\hline Model Significance & \multicolumn{2}{|c|}{0.0000} & \multicolumn{2}{|c|}{0.0000} & \multicolumn{2}{|c|}{0.0000} \\
\hline
\end{tabular}

Source: Own calculated 
Table 4. Descriptive statistics of value drivers (Sample size, $2002-2012, \mathrm{~N}=1372$ )

\begin{tabular}{|c|c|c|c|c|c|c|c|c|c|c|c|c|c|c|}
\hline \multicolumn{15}{|c|}{ Manufacturing } \\
\hline & MV & BV_L & SALES & IOC & TR & $\mathrm{NM}$ & NFA & EPS & DPS & BETA & POR & $\mathrm{AI}$ & RDI & FP \\
\hline Mean & 86.8196 & 63.7898 & 4996.0850 & 97.9537 & 7.8953 & 3.1899 & 1878.9320 & 8.6913 & 1.8560 & 0.8709 & 21.8000 & 2.4504 & 0.1362 & 5.6946 \\
\hline Median & 28.5300 & 37.0400 & 1307.2000 & 97.1413 & 7.4100 & 3.5372 & 402.8000 & 3.5900 & 0.1050 & 0.8800 & 13.4200 & 1.2424 & 0.0000 & 0.0000 \\
\hline Std. Dev. & 145.7314 & 71.9397 & 9814.5890 & 13.5494 & 5.9692 & 11.4701 & 3899.8730 & 15.3716 & 4.1249 & 0.4178 & 21.7807 & 3.1266 & 0.4091 & 15.6627 \\
\hline \multicolumn{15}{|c|}{ Chemical } \\
\hline Mean & 89.3566 & 61.4960 & 5307.7880 & 97.7225 & 8.5474 & 3.6330 & 1955.1320 & 9.1713 & 2.1704 & 0.8380 & 20.8325 & 2.9891 & 0.3645 & 24.8509 \\
\hline Median & 27.8800 & 33.5150 & 1138.8000 & 97.9263 & 8.5400 & 3.9837 & 330.9000 & 3.5050 & 0.0743 & 0.8400 & 15.2100 & 1.4844 & 0.0000 & 15.3800 \\
\hline Std. Dev. & 151.8675 & 68.6722 & 10888.2200 & 12.0275 & 5.2448 & 12.4923 & 3932.3770 & 14.7583 & 4.5411 & 0.3853 & 23.2298 & 3.6830 & 0.9999 & 25.2932 \\
\hline \multicolumn{15}{|c|}{ Machinery } \\
\hline Mean & 115.4072 & 65.5919 & 3377.7940 & 99.4421 & 9.0314 & 0.9848 & 779.9281 & 9.9962 & 2.3068 & 0.9402 & 21.1195 & 2.6721 & 0.2200 & 34.6534 \\
\hline Median & 35.7400 & 35.4450 & 972.3500 & 97.9116 & 9.0800 & 4.3926 & 241.6000 & 3.7050 & 0.0551 & 0.9500 & 16.1800 & 1.5606 & 0.0000 & 32.6700 \\
\hline Std. Dev. & 210.1164 & 75.4256 & 6048.1450 & 14.0025 & 5.5293 & 20.7219 & 1544.5250 & 17.5999 & 5.3001 & 0.3970 & 23.2926 & 3.0733 & 0.8398 & 29.9351 \\
\hline \multicolumn{15}{|c|}{ Metal } \\
\hline Mean & 65.2109 & 62.4528 & 9746.3500 & 97.8790 & 8.9962 & 4.3605 & 5120.6510 & 8.9778 & 1.2474 & 0.9947 & 12.6861 & 0.9220 & 0.0230 & 13.9965 \\
\hline Median & 29.3000 & 40.6450 & 2060.7000 & 98.6483 & 9.0350 & 3.2330 & 503.8000 & 4.3500 & 0.0000 & 1.0200 & 8.0600 & 0.4202 & 0.0000 & 7.1000 \\
\hline Std. Dev. & 88.7264 & 70.9987 & 21344.5600 & 11.1162 & 5.3487 & 8.5181 & 14238.3600 & 15.1323 & 2.4852 & 0.3681 & 16.4624 & 5.5769 & 0.1309 & 17.6176 \\
\hline \multicolumn{15}{|c|}{ NM } \\
\hline Mean & 87.4536 & 73.4621 & 6576.7970 & 97.0414 & 8.8070 & 4.1087 & 3043.3450 & 10.0889 & 1.9129 & 0.8573 & 18.2055 & 2.2028 & 0.0313 & 24.2762 \\
\hline Median & 30.0000 & 45.6100 & 1662.7500 & 96.4068 & 8.3100 & 4.3984 & 652.9000 & 4.3600 & 0.3856 & 0.9000 & 13.6100 & 1.7018 & 0.0000 & 14.4700 \\
\hline Std. Dev. & 153.1103 & 82.7258 & 12288.1200 & 12.8434 & 7.0902 & 11.3236 & 6122.0690 & 16.8516 & 3.9471 & 0.3484 & 20.8221 & 13.9046 & 0.3033 & 25.8834 \\
\hline \multicolumn{15}{|c|}{ Textile } \\
\hline Mean & 45.4812 & 56.2804 & 2658.5880 & 92.9952 & 3.5002 & 1.1564 & 1505.5460 & 4.8407 & 0.9759 & 0.8306 & 16.1721 & 2.1948 & 0.0324 & 18.6374 \\
\hline Median & 16.9300 & 32.7300 & 1168.6000 & 92.6488 & 1.7300 & 2.3822 & 557.5000 & 1.9400 & 0.0000 & 0.8600 & 8.3800 & 1.4123 & 0.0000 & 7.4500 \\
\hline Std. Dev. & 70.8351 & 65.2350 & 4095.8630 & 10.8065 & 4.1634 & 10.5993 & 2687.0800 & 12.4172 & 2.6648 & 0.3734 & 22.0857 & 3.6785 & 0.1919 & 21.7961 \\
\hline \multicolumn{15}{|c|}{ Transport } \\
\hline Mean & 135.9646 & 78.2868 & 8666.8070 & 101.5599 & 12.0384 & 4.9435 & 2367.7840 & 11.6721 & 2.7899 & 0.8479 & 24.7233 & 2.1367 & 0.2417 & 28.9103 \\
\hline Median & 67.3500 & 50.8600 & 1921.2000 & 101.3582 & 12.5700 & 4.4120 & 596.0000 & 7.4200 & 1.2847 & 0.8400 & 22.6300 & 1.1526 & 0.0000 & 26.0000 \\
\hline Std. Dev. & 181.9484 & 79.0656 & 22306.7500 & 10.7232 & 4.9225 & 6.1551 & 5502.2830 & 14.9917 & 4.9539 & 0.3307 & 21.2497 & 2.5322 & 0.5283 & 20.7276 \\
\hline \multicolumn{15}{|c|}{ FB } \\
\hline Mean & 97.9842 & 62.3320 & 4498.4170 & 102.4053 & 7.6360 & 3.1930 & 1649.0040 & 7.5307 & 1.9623 & 0.8013 & 17.8301 & 3.2983 & 0.0635 & 30.5292 \\
\hline Median & 28.0000 & 38.6650 & 1730.6000 & 97.0244 & 2.8600 & 2.2232 & 477.4000 & 3.2700 & 0.0000 & 0.7950 & 9.5500 & 1.0441 & 0.0000 & 25.3450 \\
\hline Std. Dev. & 187.4804 & 70.2418 & 6981.1860 & 27.2735 & 12.1186 & 10.7098 & 2958.7410 & 16.8878 & 6.1109 & 0.3892 & 23.5783 & 6.6445 & 0.4588 & 27.6203 \\
\hline
\end{tabular}

Source: Own calculated 
Table 5.Diagnostic tests to identify best method in determining value drivers

\begin{tabular}{c|c}
\hline F-test for fixed effects $\left(H_{0}:\right.$ parameter homogeneity $=>$ fixed effects model is misspecified $)$ \\
\hline Statistic & OLS \& FE \\
\hline F-statistic & 10.9400 \\
P-value & 0.0000 \\
\hline Breusch and Pagan LM test for random effects $\left(H_{0}:\right.$ the variances across entities is zero $)$ \\
\hline Statistic & OLS \& RE \\
\hline Chi-statistic & 1012.9000 \\
P-value & 0.0000 \\
\hline Hausman test statistic $\left(H_{0}\right.$ : regressors are not correlated with c = > random effects $)$ \\
\hline Statistic & FE \& RE \\
\hline Chi-statistic & 1724.3900 \\
P-value & 0.0000 \\
\hline
\end{tabular}

Source: Own calculated

Note on diagnostic test results of table 5:

The diagnostic test results in table 5 for panel regression methods used in table 3 reveals that in case of panel-OLS and FE, FE comes out to be a better model, in case of panel-OLS and RE, RE comes out to be a better model and in case of FE and RE, FE comes out to be the better model as p-values of all the diagnostic tests were less than 0.05 . From here we choose FE to be the best model for our study.

\subsection{Sectorial sensitivity of value drivers}

After analysing the value drivers for the manufacturing sector, it is of interest to study about the drivers for different sub-sector of manufacturing industry. Because there is a possibility that drivers may not be constant across sectors. Therefore, this sensitivity analysis will give us a clear idea as to which are the key drivers one should concentrate onwhen analysing sectors. Taking the notion further that fixed effects model is better than panel OLS and random effects model, for the ease of exposition we only report the results of fixed effects model in table 6.

In the chemical industry;sales, net margin, earnings per share, dividend per share, book value and tax rate are the six major drivers of value. The capital expenditure for chemical industry is coming out to be significant at 10 percent level, suggesting that there are some levels of expansion/capacity overhauling in this sector.Among the strategic drivers only the advertising i.e. image building is coming out to be significant. This suggests that chemical sector has invested significant amount in improving its brand image. This is also substantiated by the fact that the pay-out ratio is not significant for chemical industry, suggesting that there is high-degree of retention of profit, which is channelized into image building. The research and development driver is not significant, which coincides with the fact that the level of investment is $R \& D$ is actually very decimal (only 0.5 percent to sale in comparison to 4 percent in the global context ${ }^{14}$ ).

\footnotetext{
${ }^{14}$ Report on Indian Chemical Industry, XIIth five year plan (planning commission of India).
} 
In case of machinery; sales, earning per share, dividend per share, book value and beta are the five main financial drivers. Among the strategic drivers, $R \& D$ and foreign promoters are positively linked with the value of the firm.

In the metal industry; sales, intensity of operating expenses, capital expenditure, earning per share and beta are the five main drivers of value. The R\&D is the only strategic driver that has a significant role in the determination of value for metal industry. The negative coefficient of the R\&D suggests that most probably the effort towards strengthening R\&D is a recent one, which is yet to translate into output. The insignificance of dividend per share can be attributed to the fact that profits have been channelized into expansion and R\&D.

The non-metal industry bears a similar picture as that of the metal industry. The financial drivers are almost similar except beta which is not significant. However, among the strategic drivers the foreign promoters have a significant relationship with the value of firm. Pay-out ratio has inversely significant relation with value meaning that high pay-outs may lead to decline in value.

The textile industry depicts a different picture from the perspective of financial drivers. Earnings per share, dividend per share, beta, and book value are the four main financial drivers of value. R\&D is the strategic driver of value. Quite surprisingly, the sales is not the driver of value. This is the only segment where sales is not playing a role in the value determination. This is also supported by the net margin driver, which is also insignificant for textile. One possible explanation for this could be that during the study period, the textile industry has seen a sharp drop in its growth. Moreover, in cotton industry exports were banned for few years ${ }^{15}$.

Moving on to the transport segment, it is noticed that the results on the similar lines with that of manufacturing segment for the financial drivers. The main financial drivers for this segment are sales, net margin, earnings per share, dividend per share, beta, and book value. However, one of the most significant aspects of this segment is the complete lack of strategic drivers. One plausible explanation for this could be the structural weakness in this segment in terms of high capacity additions and intensifying competition. There is also limited inflow of FDI into this sector, forcing companies to curtail their spending on R\&D and the eminent competition with global players play a substantial role in companies trying to manage their financials rather than the strategic drivers.

As expected, in the food and beverage industry the major strategic driver is the image building i.e. advertising. Among the financial drivers; sales, net margin, earnings per share, and book value have a significant relationship with the value of the firm.

From the sectorial analysis, it is observed that each sector has its unique characteristics, hence, the financial drivers and strategic drivers differ from sector to sector except sales and earnings per share that are common drivers of value across all sectors. Therefore, the

\footnotetext{
15 The government banned export of raw cotton at the start of 2011, halting all export of cotton from India. Hence cotton prices started falling due to the slowdown in demand. To arrest the fall and boost, the government allowed additional exports of 170 million $\mathrm{kg}$ in mid-2011. However prices kept declining due to a lull in demand, both in global and domestic market (CRISIL textile report, 2012).
} 
Managers of the firm's should possess a fair idea of these drivers relevant to the specific sectors, so that they can work on these drivers to enhance value.

Table6. Panel multivariate regression of value drivers (sectors)

\begin{tabular}{|c|c|c|c|c|c|c|c|c|c|c|c|c|c|c|}
\hline \multicolumn{15}{|c|}{ Sample size, $2002-2012, N=1372$} \\
\hline \multirow{2}{*}{ Statistic } & \multicolumn{2}{|c|}{ Chemical } & \multicolumn{2}{|c|}{ Machinery } & \multicolumn{2}{|c|}{ Metal } & \multicolumn{2}{|c|}{ Non-metal } & \multicolumn{2}{|c|}{ Textile } & \multicolumn{2}{|c|}{ Transport } & \multicolumn{2}{|c|}{ FB } \\
\hline & Coefficient & t-Statistic & Coefficient & t-Statistic & Coefficient & t-Statistic & Coefficient & t-Statistic & Coefficient & $\mathrm{t}$-Statistic & Coefficient & t-Statistic & Coefficient & t-Statistic \\
\hline$\beta_{0}$ & $46.1840^{*}$ & 2.7509 & $-55.6814^{*}$ & -1.8094 & $78.9218^{*}$ & 3.2740 & $57.2864^{*}$ & 2.0681 & $22.9443^{* * *}$ & 1.7679 & $-128.0440^{* * *}$ & -1.7281 & $47.2656^{* * *}$ & 1.6791 \\
\hline S & $0.0472^{*}$ & 12.5637 & $0.0129^{*}$ & 10.5598 & $0.0138^{*}$ & 5.6596 & $0.0310^{*}$ & 5.9832 & 0.0063 & 0.8197 & $0.0367^{*}$ & 5.9956 & $0.0535^{*}$ & 5.0841 \\
\hline IOC & 0.0551 & 0.3304 & -0.1630 & -0.5858 & $-0.7939^{*}$ & -3.2312 & $-0.4207^{* *}$ & -1.6341 & -0.0688 & -0.5049 & 0.8673 & 1.1244 & -0.3006 & -1.2334 \\
\hline $\mathrm{TR}$ & $-2.7376^{*}$ & -6.0575 & $3.9126^{*}$ & 4.6766 & $1.0545^{* * *}$ & 1.7735 & $1.8773^{* *}$ & 1.9893 & 0.0473 & 0.1336 & -0.0723 & -0.0553 & -0.4788 & -0.4784 \\
\hline NM & $0.6783^{*}$ & 4.5808 & -0.2325 & -1.2709 & 0.0798 & 0.2571 & 0.1137 & 0.3826 & 0.1058 & 0.8465 & $3.8482 *$ & 4.7830 & $1.1405^{*}$ & 2.6271 \\
\hline CAPEX & $0.0019^{* *}$ & 1.8576 & 0.0086 & 1.4502 & $0.0022^{*}$ & 5.2206 & $0.0044^{*}$ & 3.0564 & 0.0013 & 1.1166 & -0.0010 & -0.5559 & 0.0021 & 0.8486 \\
\hline BV_L & $0.2111^{*}$ & 5.6143 & $0.4066^{*}$ & 5.5546 & 0.0246 & 0.6664 & 0.0580 & 1.0776 & $0.0993 *$ & 2.8617 & $0.4266^{*}$ & 5.1899 & $0.2403 *$ & 2.6134 \\
\hline EPS & $1.8363^{*}$ & 9.6400 & $3.6650^{*}$ & 11.5474 & $1.4485^{*}$ & 6.5549 & $1.8802^{*}$ & 7.0006 & $1.4853^{*}$ & 10.7187 & $1.9096^{*}$ & 3.5545 & $2.3263 *$ & 6.7259 \\
\hline DPS & $1.8648^{*}$ & 3.5400 & $4.2147^{*}$ & 5.3078 & 0.4888 & 0.3977 & $1.6422 * * *$ & 1.8823 & $1.8900^{*}$ & 3.6017 & $2.5080^{* *}$ & 2.0155 & -0.4942 & -0.5684 \\
\hline BETA & -3.4704 & -0.7974 & $17.6255^{* *}$ & 1.9643 & $12.6804^{* *}$ & 2.3963 & 3.4833 & 0.3529 & $14.3854^{*}$ & 4.2312 & $73.3566^{*}$ & 4.8353 & 14.6716 & 1.1867 \\
\hline POR & -0.0601 & -0.7211 & $-0.3182 * *$ & -1.9985 & 0.0427 & 0.3160 & $-0.5801^{*}$ & -3.7228 & -0.0004 & -0.0076 & -0.2320 & -0.9743 & 0.2214 & 1.1650 \\
\hline AI_d & $25.3622^{*}$ & 3.4515 & 15.8100 & 0.9040 & 13.0563 & 0.4233 & -1.2348 & -0.0850 & -11.1945 & -1.4021 & -33.1229 & -0.9667 & $48.6364^{* *}$ & 2.2104 \\
\hline RDI_d & -9.0686 & -1.1084 & $49.2971^{*}$ & 2.7514 & $-129.2330^{*}$ & -3.3121 & -0.2328 & -0.0155 & $38.3721 *$ & 1.9538 & 17.8360 & 0.6864 & -20.4603 & -0.2837 \\
\hline FP_d & 1.0992 & 0.1354 & $58.3351^{*}$ & 3.5846 & 1.9386 & 0.1991 & $51.2832^{*}$ & 18.5931 & 1.0042 & 0.1352 & 24.0841 & 1.1014 & 27.9474 & 0.6733 \\
\hline $\mathrm{R}$ square & \multicolumn{2}{|c|}{0.5986} & \multicolumn{2}{|c|}{0.6552} & \multicolumn{2}{|c|}{0.4495} & \multicolumn{2}{|c|}{0.4513} & \multicolumn{2}{|c|}{0.5929} & \multicolumn{2}{|c|}{0.5411} & \multicolumn{2}{|c|}{0.6587} \\
\hline \multicolumn{15}{|l|}{ Model } \\
\hline Significance & \multicolumn{2}{|c|}{0.0000} & \multicolumn{2}{|c|}{0.0000} & \multicolumn{2}{|c|}{0.0000} & \multicolumn{2}{|c|}{0.0000} & \multicolumn{2}{|c|}{0.0000} & \multicolumn{2}{|c|}{0.0000} & \multicolumn{2}{|c|}{0.0000} \\
\hline
\end{tabular}

Source: Own calculated

\section{Conclusion}

We set out to examine the major drivers of value in Indian manufacturing industry. To achieve the set objectives, we first derive the probable drivers of value by creating a value metric framework. Further, we create an econometric model to analyse the sensitivity of these probable drivers of value. Our results suggest that sales, net margin, book value, dividend per share, beta and earnings per share are the six major financial drives. Interestingly all the probable strategic drivers (pay-out policy, brand image, investments into R\&D and foreign promoters holding in organisational structure) when included in the model have significant relation with value, with no impact on r-square. Hence, it can be safely argued that apart from generic financial drivers, firms need to put more stress on strategic choices they make, because it is the strategic choice that will give firms an edge over others in developing economies like India. Moreover, these drivers vary from sector to sector except sales and earnings per share that are constant across all sectors (see table 6). Therefore, firms in 
emerging economies like India should concentrate on these specific financial and strategic value drivers (relevant to that particular sector) that will have the greatest impact on value. Focusing on these value drivers will enable management to translate the broad objective of creating value into some explicit actions more likely to deliver that value, this will make the destinations i.e. emerging economies remain attractive for investment. Moreover, the empirical results of the study produce different set of drivers compared to the set of drivers prescribed by previous studies (Ruhl and Cowen (1990), Mills and Print (1995), Scarlet (1997), Rappaport (1998), Turner (1998), Akalu (2002), Gross (2006), Damodaran (2006) among others).

The research results can be used in practice when making decisions on organizations' value enhancement as well as assessing the influence of the changes upon the organization's value in the organization's environment. The created model of value drivers can be applied when analysing the sensitivity of organizations' value for different drivers in other developing countries too. But since the level of economic, political and social development is different it may lead to biased decision making. We therefore encourage researchers to come up with similar studies in developing economies that may help firms understand the dynamics of value drivers. These studies will further benefit researchers in arriving at common consensus forvaluedrivers in emerging economies.

\section{References}

Akalu, M.M. (2002). Measuring and Ranking Value drivers (No. 043/02).Tinbergen Institute Discussion Paper. http://papers.tinbergen.nl/02043.pdf.

Al-Hares, O. M., Abu Ghazaleh, N. M., \&Hadda, A. E. (2012). Value relevance of earnings, book value and dividends in an emerging capital market: Kuwait evidence. Global Finance Journal, 23(3), 221-234.http://dx.doi.org/10.1016/j.gfj.2012.10.006

Baltagi, B. (2008). Econometric Analysis of Panel Data (4 ed.). John Wiley \& Sons.

Bernard V. (1995). The FelthamOhlsonFramwork: Implication for Empiricists. Contemporary Accounting Research, 11(2), 733-747.http://dx.doi.org/10.1111/j.1911-3846.1995.tb00463.x

Black, A., \& Wright, P. (2001).In Search of Shareholder Value: Managing the Drivers of Performance (2 ed.). Financial Times Prentice Hall.

Boyd, B. (2010). Business Exit Strategies: Value Drivers White Papers. Business Enterprise Institute Inc. http://www.business exit-strategies.com/exit-planning-white-papers.html.

Chandra, P. (2011). Corporate Valuation and Value Creation (1 ed.). Delhi: Tata McGraw-Hill Education.

Chang, Y. Y., \& Hughes, M. (2012). Drivers of Innovation Ambidexterity in Small to Medium sized Firms. European Management Journal, 1-17.http://dx.doi.org/10.1016/j.emj.2011.08.003

Cheremnikh, O. (2000). Improving the Company's Value - Purpose Business Management.Education and Business, 44-68. 
Chugh, L. C., \& Meador, J. W. (1984). The Stock Valuation Process: The Analysts' view. Financial Analysts Journal, 40(6), 41-48. http://dx.doi.org/10.2469/faj.v40.n6.41

Copeland, T., Koller, T., \& Murrin, J. (2000). Valuation: Measuring and Managing the Value of Companies (3 ed.). New York: Wiley.

Courteau, L., Kao, J., \& Richardson, G. K. (2000). The Equivalence of Dividend, Cash Flows and Residual Earnings Approaches to Equity Valuation Employing Ideal Terminal Value Expressions.Working paper. Available at SSRN: http://papers.ssrn.com/sol3/papers.cfm?abstract_id=233399.

Damodaran, A. (2006). Security Analysis for Investment and Corporate Finance (2 ed.). India: Wiley.

Dechow, P. M., Hutton, A. P., \& Sloan, R. G. (1999). An Empirical Assessment of the Residual Income Valuation Model. Journal of Accounting and Economics, 26(1), 1-34. http://dx.doi.org/10.1016/S0165-4101(98)00049-4

Dermine, J. (2009). Bank Valuation and Value-Based Management. New Delhi: Tata McGraw-Hill.

Francis, J., Olsson, P.,\& Oswald, D. (2000). Comparing the Accuracy and Explainability of Dividend, Free Cash Flow, and Abnormal Earnings Equity Value Estimates.Journal of Accounting Research, 38(1), 45-70. http://dx.doi.org/10.2307/2672922

Frankel, R., \& C. Lee (1995).Accounting Diversity and International Valuation.Working paper, University of Michigan and Cornell University.

Frankel, R., \& Lee, C. (1996).Accounting Diversity and International Valuation.Working paper, University of Michigan and Cornell University. http://papers.ssrn.com/sol3/papers.cfm?abstract_id=2658.

Grjaznovoj A. G., \&Fedotovoj, M. A. (1998).A business Estimation. The Finance and Statistics, Moscow. Cited in Kazlauskiene V., \&Christauskas, C. (2008). Business Valuation Model Based on the Analysis of Business Value Drivers. Engineering Economics, 57(2), 23-31.

Gross, S. (2006). Banks and Shareholder value: An Overview of Bank Valuation and Empirical Evidence on Shareholder Value for Banks (1 ed.). DeutscherUniversitats-Vlg.

Imam, S., Chan, J.,\& Ali-Shah, S. Z. (2013). Equity Valuation Models and Target Price Accuracy in Europe: Evidence from Equity Reports. International Review of Financial Analysis, 28, 9-19. http://dx.doi.org/10.1016/j .irfa.2013.02.008.

Ittner, C. D., \&Larcker, D. F. (2001).Assessing Empirical Research in Managerial Accounting: A Value Based Management Perspective. Journal of Accounting \& Economics, 32(12), 349-410.http://dx.doi.org/10.1016/S0165-4101(01)00026-X

Kakati, M. (2005). Stock Valuation Process: A Practitioners' view. Finance India, 19(2), 513-523. 
Kaplan, R.S., \& Norton, D. P. (1996).Using the Balanced Scorecard as a Strategic Management System. Harvard Business Review, 74(1), 75-85.

Kazlauskiene V., \&Christauskas, C. (2008). Business Valuation Model Based on the Analysis of Business Value Drivers. Engineering Economics, 57(2), 23-31.http://verslokelias.eu/resursu_katalogas/content/article/straipsniai\%20mokslines\%20inf ormacijos $\% 20$ instituto $\% 20$ (ISI) $\% 20$ pagrindinio $\% 20$ saraso $\% 201$ eidiniuose $/ 5 . \% 20$ mokslines $\%$ 20informacijos $\% 20$ instituto\%20Nr1.pdf.

Kim, K. (2004). Strategic Planning for Value-Based Management: An Empirical Examination. Management Decisions, 42(8), 938-948. http://dx.doi.org/10.1108/00251740410555434

Kraai, J. (2006). Value Drivers: How do they affect your Business Value.Vancouver Business Journal. http://www.vbjusa.com/focus-sections/banking-finance.

Lee, C., J. Myers, \&Swaminathan, B. (1999). What is the Intrinsic Value of Dow? Journal of Finance, 54(5), 1693-1741.http://dx.doi.org/10.1111/0022-1082.00164

LEK Consulting.(1998).Identifying and Managing Key Value drivers.LEK Consulting Executive Insights, 1(1). www.lek.com.

Mills, R., \& Print, C. (1995).Strategic Value Analysis.Management Accounting, 73(2), 35-37.

Penman, S., \&Sougiannis, T. (1998).A Comparison of Dividend, Cash Flow, andEarnings Approaches to Equity Valuation. Contemporary Accounting Research, 15(3), 343-383. http://dx.doi.org/10.1111/j.1911-3846.1998.tb00564.x

Rappaport, A. (1998). Creating Shareholder Value: A Guide for Managers and Investors. New York: Simon and Schuster.

Reyna, O. T. (2010). Panel Data Analysis: Fixed and Random effects. Data and statistical services, Princeton University, Princeton.http:// www.princeton.edu/ otorres/ Panel101R.pdf.

Ripol-Saragosi, F. B. (2001). Bases of Estimated Assets: Studies. Moscow: PRIOR Publishing house.

Ruhl, J., \& S. Cowen (1990). How An in House System can Create Shareholder Value?.Financial Executive, 6(1), 53-57.

Salomo, S., \& N. Strecker (2009).Innovation Strategy and Firm Performance: An empirical study of publicly listed firms.Springer.

Scarlett R.C. (1997). Value- Based Management.London: CIMA Publishing.

Sheppard, K. (2010). Financial Econometrics Notes.Oxford University, Oxford.www.kevinsheppard.com/images/d/de/Financial_Econometrics_2013-2014_tablet.pdf

Subrahmanyan, K. R., \&Venkatachalam, M. (2007).Earnings, Cash Flows and Ex post Intrinsic Value of Equity.The Accounting Review, 82(2), 457-481.http://dx.doi.org/10.2308/accr.2007.82.2.457 


\section{Macrothink}

Asian Journal of Finance \& Accounting ISSN 1946-052X

Turner, R. (1998). Projects for Shareholder Value: The Influence of Project Performance Parameters at different Financial Ratios. Project Management, 4(1), 70-74. http:/www.kupasazshomal.com/Editor/assets/magazine/International\%20Project\%20Manage ment\%20Journal\%20,1998.pdf.

Walter, J. E. (1963). Dividend policy: its influence on the value of the enterprise. Journal of Finance,18(2), 280-291. http://dx.doi.org/10.1111/j.1540-6261.1963.tb00724.x

Xavier, A., \& P. Vinolas (2003). FEVA: A Financial and Economic Approach to Valuation. Financial Analysts Journal, 59(2), 80-87.http://dx.doi.org/10.2469/faj.v59.n2.2516 